\title{
Selecting and using nebuliser equipment
}

\author{
A H Kendrick, E C Smith, R S E Wilson
}

Aim of nebuliser therapy

The aim of nebuliser therapy is to deliver a therapeutic dose of the desired drug in the form of an aerosol of respirable particles within a fairly short period of time, usually 5-15 minutes. To achieve this, nebuliser systems should be expected to provide a drug output with about $50 \%$ of the particles below output with about $50 \%$ of the particles below
$5.0 \mu \mathrm{m}$ mass median diameter. It is important to obtain an acceptable range of aerosol particle sizes because of the way in which these are deposited in the tracheobronchial tree..$^{1-5}$

\section{Practical definitions}

fet nebuliser: a nebulising chamber where an aerosol is generated from a flow of gas from an electrical compressor or from a compressed gas supply (air or oxygen). The gas passes through a very small hole (the jet or Venturi) resulting in liquid being sucked up through the small hole from the chamber base and atomised. The resultant large particles then impact upon The resultant large particles then impact upon
baffles to generate small respirable particles.

Ultrasonic nebuliser: an electrically driven system whereby a rapidly vibrating piezoelectric crystal vibrates the drug solution and produces aerosol particles of a respirable size. ${ }^{\circ}$

Flow rate through the nebuliser: the flow rate of gas, whether from a compressed source or from a compressor, that actually drives the nebuliser chamber. It is not the same as the flow rate from the compressor which will often be considerably higher. ${ }^{7}$ It is obtained by producing a pressure-flow rate curve for the nebuliser. Recordings of from zero from zero flow (maximum pressure) to max
imum flow (minimum pressure) using a rotameter, a compressor unit (or flow generator), meter, a compressor unit (or flow generator),
and pressure measuring device. By substituting the nebuliser chamber for the rotameter the pressure in the circuit can be obtained with a constant flow rate from the flow generator. From the pressure-flow curve the flow rate at the nebuliser can be obtained.

Volume output from the nebuliser: the volume of solution leaving the nebuliser chamber. Whilst useful as a general guide to nebuliser performance, it does not give precise information about the actual drug output.

Drug output from the nebuliser: the actual amount of drug that is released during nebulisation. Because of a variety of factors, including evaporation, a precise measure of drug cluding evaporation, a precise measure of drug
output (as opposed to volume output) must be output (as opposed to volume output)
assessed using marker techniques.

Residual volume: the volume of solution left in a nebuliser chamber once nebulisation has ceased and all of the aerosol particles have been generated and have left the nebuliser chamber. It is an important volume to take into account when determining the fill volume required to deliver a drug to a patient 9

Fill volume: the volume of drug solution initially put into the nebuliser chamber. It must exceed the residual volume by a sufficient amount to provide therapeutic benefit to the patient. ${ }^{9}$ It is suggested that it should be at least twice the residual volume. It is important to be aware be aware nebuliser drugs in prepackaged ampoules.

The definitions of aerosol output, respirable particles, mass median diameter (MMD), mass median aerodynamic diameter (MMAD), respirable output, and respirable fraction are given in the paper by O'Callaghan and Barry on page S35.

Factors affecting nebuliser performance The general term "nebuliser" usually implies the combination of the nebuliser chamber and the compressor. Jet nebulisers usually have a constant output, but to prevent wastage new breath-enhanced nebulisers are available where the output is enhanced in the inhalation phase. Ultrasonic nebulisers are effective but are less robust and more expensive than jet nebuliser systems and are generally not used for regular domiciliary therapy.

The major use of nebuliser systems is to deliver bronchodilator therapy. The specification of the nebuliser chamber for administering bronchodilators is different from that required to deliver other drugs such as antibiotics or pentamidine.

The output of a nebuliser is determined by a combination of factors which must be taken into account, and will depend on (1) the design of the nebuliser chamber, ${ }^{6}(2)$ the flow of the driving gas and the performance characteristics of the compressor, ${ }^{71011}$ (3) the volume of solution (fill volume) of the drug at the start of nebulisation, ${ }^{912}$ (4) the time taken to nebulise the solution of drug ${ }^{79}(5)$ the viscosity, surface tension, and concentration of the drug solution, ${ }^{13}$ (6) the residual volume, ${ }^{9}$ and (7) tapping of the nebuliser chamber during nebulisation.

The volume output and particle size of water, saline, salbutamol, terbutaline, and ipratropium bromide are similar. ${ }^{14}$ For more viscous solutions the volume output is much slower (fig 1) 1315 The output of steroids may a suspension. However, the volume output from a nebuliser is not directly related to the drug output, ${ }^{8}$ and the drug output and its availability are different between bronchodilators, antibiotics, and steroids. Measuring volume output is simple and provides a guide to the performance of nebuliser/compressor combinations. ${ }^{716}$ 


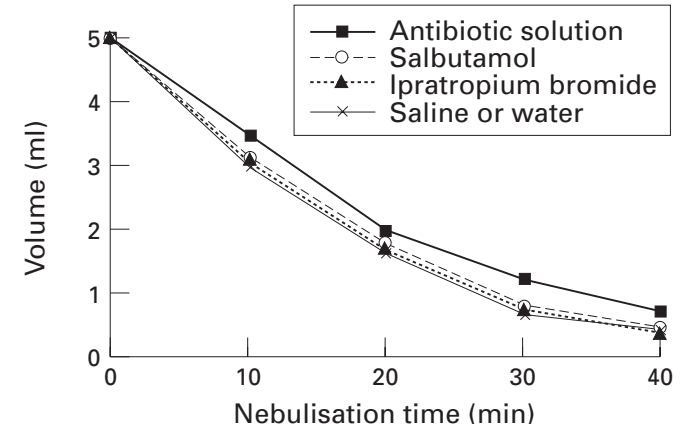

Figure 1. The output of water/saline, salbutamol, ipratropium bromide, and an antibiotic solution. Those solutions with a specific gravity of 1 have similar rates of slightly slower rate of output. Data from reforence 14.

\section{Selecting nebulisers and compressors}

The choice of nebuliser and compressor depends on various factors including cost, ease of use and of maintenance, and overall performance. There are many nebuliser chambers and compressors available. Choice should be based on assessment of the systems and comments from other users. It is not advisable simply to pick a nebuliser chamber and a compressor at random. As will be discussed below, the matching of a nebuliser and compressor is important to achieve optimal performance. Furthermore, under certain circumstances par-

Table 1 Examples of combinations of compressors and nebuliser chambers supplied for bronchodilator therapy. The compressors have been didided into high, medium, and low flow rates and have been used with the nebuliser chambers

\begin{tabular}{|c|c|c|c|}
\hline Flow rate & Compressor & $\begin{array}{l}\text { Nebuliser chambers sold } \\
\text { with compressor unit }\end{array}$ & Multivolt? \\
\hline $\begin{array}{l}\text { High flow rate } \\
(>6.01 / \mathrm{min})\end{array}$ & $\begin{array}{l}\text { AFP Classic } \\
\text { AFP Aquillon } \\
\text { AFP Ultima } \\
\text { AFP Tourer } \\
\text { Flaem Nuova Combineb } \\
\text { Flaem Nuova Micelfuss Pro } \\
\text { Medic-Aid CR50 } \\
\text { Medic-Aid CR60* } \\
\text { Medic-Air Freeway } \\
\text { Gast*'† } \\
\text { Inspiron* } \\
\text { Medix M Flo } \\
\text { Medix AC2000* } \\
\text { Medix World Traveller } \\
\text { Medix Econoneb } \\
\text { Medix Minor*' } \\
\text { Medix Turboneb } \\
\text { Porta-Neb } \\
\text { Porta-Neb Multi } \\
\text { SunMist Plus }\end{array}$ & $\begin{array}{l}\text { MicroMist } \\
\text { MicroMist } \\
\text { MicroMist } \\
\text { MicroMist } \\
\text { Flaem Nuova Type } 3 \\
\text { Flaem Nuova Type 2 } \\
\text { Medic-Aid Sidestream } \\
\text { Medic-Air Ventstream } \\
\\
\text { MiniNeb, Incenti-Neb } \\
\text { Medix A11 } \\
\text { Medix A11 } \\
\text { Medix A11 } \\
\text { Medix A11 } \\
\text { Cirrus } \\
\text { Cirrus } \\
\text { Medic-Aid Sidestream } \\
\text { Medic-Aid Ventstream } \\
\text { Medic-Aid Sidestream } \\
\text { Perma Neb }\end{array}$ & $\begin{array}{l}\text { No } \\
\text { No } \\
\text { Rechargeable battery } \\
\text { Yes } \\
\text { Yes } \\
\text { Yes } \\
\text { No } \\
\text { No } \\
\text { Yes } \\
\text { ? } \\
\text { No } \\
\text { No } \\
\text { No } \\
\text { Yes } \\
\text { No } \\
\text { No } \\
\text { No } \\
\text { No } \\
\text { Yes } \\
\text { No }\end{array}$ \\
\hline $\begin{array}{l}\text { Medium flow rate } \\
(4.0-6.01 / \mathrm{min})\end{array}$ & $\begin{array}{l}\text { Aeroneb HP† } \\
\text { Atomolette } \dagger \\
\text { Flaem Nuova M70 } \\
\text { NebuPump† } \\
\text { Novair II } \\
\text { Pari InhalierBoy† } \\
\text { Pari TurboBoy } \\
\text { Pari JuniorBoy } \\
\text { Pulmo-Aide† } \\
\text { SunMist } \\
\text { DeVilbiss Traveller }\end{array}$ & $\begin{array}{l}\text { Cirrus } \\
\text { Own } \\
\text { Flaem Nuova Type } 2 \\
\text { Acorn } \\
\text { Cirrus } \\
\text { Own } \\
\text { Pari LC Plus, LC Plus Junior } \\
\text { Pari LC Plus, LC Plus Junior } \\
\text { Own } \\
\text { Perma Neb } \\
\text { Perma Neb }\end{array}$ & $\begin{array}{l}\text { No } \\
\text { No } \\
\text { No } \\
\text { No } \\
\text { No } \\
\text { No } \\
\text { No } \\
\text { No } \\
\text { No } \\
\text { No } \\
\text { Yes }\end{array}$ \\
\hline $\begin{array}{l}\text { Low flow rate } \\
(<4.01 / \mathrm{min})\end{array}$ & $\begin{array}{l}\text { Aeroneb Standard } \dagger \\
\text { Pari WalkBoy } \\
\text { Aeroneb HP† }\end{array}$ & $\begin{array}{l}\text { Own, Cirrus } \\
\text { Pari LC Plus, } \\
\text { Own }\end{array}$ & $\begin{array}{l}\text { No } \\
\text { Yes } \\
\text { No }\end{array}$ \\
\hline Others & $\begin{array}{l}\text { Aerolyser CF1B } \dagger \\
\text { Aerolyser CF1R† } \\
\text { Aerolyser } 216 \dagger \\
\text { Flaem Nouva Travelneb } \\
\text { Henley HCU-1† }\end{array}$ & $\begin{array}{l}\text { Wright } \\
\text { Respi-Neb } \\
\text { Respi-Neb } \\
\text { Flaem Nuova Type } 3 \\
\text { Hudson MK II }\end{array}$ & $\begin{array}{l}\text { Yes } \\
\text { Yes } \\
\text { Yes } \\
\text { Yes } \\
\text { Yes }\end{array}$ \\
\hline
\end{tabular}
* Wilson and Steventon have tested these compressors with 19 nebuliser chambers: Acorn, Aerflo, Cirrus, DeVilbiss, Econoneb,
Hudson II, Jet set, Microcirrus, MicroNeb III, MiniNeb, Sandoz, Suremist, Turret Turbo, Unicorn, Unimist, Unineb, Upmist and Wee Neb. With these compressors they all achieved flow rates at the nebuliser of $>6.01 / \mathrm{min}$. ticular types of nebuliser or combinations of nebuliser and compressor will be required. The final choice of equipment should be made by departments acting in isolation.

Specific information will be required to assist the choice. For the nebuliser this should include data on the flow rate at the nebuliser, residual drug) output at five and 10 minutes, the MMD
(or MMAD), and the percentage of particles under $5 \mu \mathrm{m}$. For the compressor the size, weight, noise levels, and ease of use are important considerations for patients and their provide on the clinical use of the system should also be obtained.

\section{Nebuliser/compressor combinations}

The performance of a given nebuliser chamber is closely linked to the flow of the driving gas and, hence, the performance of the compressor therefore important to use a combination of nebuliser chamber and compressor that delivers an acceptable volume output of drug, with an acceptable range of respirable particles, over an acceptable period of time to the
patient. ${ }^{7216-23}$ volume, maximum fill volume, the volume (or families. Any clinical data that the supplier can 
Table 2 Details of nebuliser chambers. For each chamber the residual volume, maximum fill volume, the percentage of particles under $5 \mu \mathrm{m}$, and the mass median diameter (MMD) is given. The percentage of solution nebulised at five and

\begin{tabular}{|c|c|c|c|c|c|c|}
\hline \multirow{2}{*}{$\begin{array}{l}\text { Nebuliser } \\
\text { chamber }\end{array}$} & \multirow{2}{*}{$\begin{array}{l}\text { Residual } \\
\text { volume }\end{array}$} & \multirow{2}{*}{$\begin{array}{l}\text { Maximum } \\
\text { fill volume (ml) }\end{array}$} & \multicolumn{2}{|c|}{$\%$ nebulised } & \multirow{2}{*}{$\begin{array}{l}\% \text { particles } \\
\text { under } 5 \mu m\end{array}$} & \multirow{2}{*}{$\begin{array}{l}M M D D \\
(\mu m)\end{array}$} \\
\hline & & & 5 minutes & 10 minutes & & \\
\hline Acorn & 1.76 & 15 & & 38 & 79 & 3.69 \\
\hline A11 & 1.1 & $?$ & 30 & 38 & 58 & 4.42 \\
\hline $\begin{array}{l}\text { Aeroflo } \\
\text { Aeroneb }\end{array}$ & $?$ & $\stackrel{?}{?}$ & $\stackrel{?}{9}$ & $3 ?$ & 30 & $?$ \\
\hline $\begin{array}{l}\text { Aeroned } \\
\text { Aeromist }\end{array}$ & $?$ & $?$ & ? & $\begin{array}{c}00 \\
?\end{array}$ & ? & ? \\
\hline Aiolos & $?$ & $?$ & $?$ & $?$ & $?$ & $?$ \\
\hline Atomolette & ? & $?$ & 33 & 36 & 28 & 7.60 \\
\hline Ava Neb 1780 & $?$ & $?$ & 32 & 48 & 58 & 4.30 \\
\hline Cirrus & 0.9 & 10 & 40 & 46 & 80 & 3.50 \\
\hline $\begin{array}{l}\text { Cloud Chamber } \\
D e V i b i s s 646\end{array}$ & $?$ & 10 & $?$ & $?$ & 42 & $?$ \\
\hline $\begin{array}{l}\text { DeVilbiss } 646 \\
\text { Econoneb }\end{array}$ & 2.1 & $\begin{array}{r}3 \\
25\end{array}$ & 26 & 44 & $\begin{array}{l}70 \\
40\end{array}$ & 2.20 \\
\hline Flaem Nuovo Type 2 & 0.5 & 7.0 & ? & $?$ & $\stackrel{40}{?}$ & 1.32/2.36* \\
\hline Flaem Nuovo Type 3 & 0.5 & 8.0 & ? & $?$ & $?$ & $1.07 / 4.64^{*}$ \\
\hline $\begin{array}{l}\text { Hudson Neb MKII } \\
\text { Hudson UD I }\end{array}$ & $\stackrel{?}{3}$ & $?$ & 50 & 57 & 82 & 2.60 \\
\hline $\begin{array}{l}\text { Hudson UD I } \\
\text { Hudson UD II }\end{array}$ & $\begin{array}{l}2.3 \\
1.4\end{array}$ & 17 & $2 ?$ & $?$ & 82 & 4.80 \\
\hline $\begin{array}{l}\text { Hudson UD II } \\
\text { Incenti-Neb }\end{array}$ & $\begin{array}{c}1.4 \\
? \\
?\end{array}$ & $\begin{array}{l}10 \\
20\end{array}$ & $\begin{array}{c}25 \\
?\end{array}$ & $\begin{array}{c}33 \\
?\end{array}$ & $\begin{array}{l}79 \\
54\end{array}$ & $\begin{array}{c}3.29 \\
?\end{array}$ \\
\hline Jet set & $?$ & $?$ & $?$ & $?$ & $?$ & $?$ \\
\hline $\begin{array}{l}\text { MicroCirrus } \dagger \\
\text { MicroMist }\end{array}$ & 1.2 & 10 & $?$ & $?$ & 90 & 1.20 \\
\hline $\begin{array}{l}\text { MicroMist } \\
\text { MirroNeb }\end{array}$ & 0 & 10 & 28 & ?ִ & $\begin{array}{l}76 \\
78\end{array}$ & $\begin{array}{l}2.10 \\
3.63\end{array}$ \\
\hline $\begin{array}{l}\text { MircroNeb } \\
\text { MiniNeb }\end{array}$ & $\begin{array}{l}0.9 \\
2.3\end{array}$ & $\begin{array}{l}13 \\
38\end{array}$ & $\begin{array}{l}28 \\
41\end{array}$ & $\begin{array}{l}59 \\
51\end{array}$ & $\begin{array}{l}78 \\
79\end{array}$ & $\begin{array}{l}3.63 \\
3.54\end{array}$ \\
\hline Pari Boy & 2.0 & $\begin{array}{r}50 \\
9\end{array}$ & 50 & 64 & 64 & 4.16 \\
\hline Pari LC Plus & 1.0 & 8 & 50 & $\begin{array}{l}54 \\
50\end{array}$ & $\begin{array}{l}84 \\
60\end{array}$ & 3.80 \\
\hline Pari LC Plus Junior & 0.9 & 8 & 55 & 55 & 54 & 4.60 \\
\hline Perma Neb & 1.2 & 9 & 39 & 75 & 70 & 2.50 \\
\hline Raindrop & $?$ & $?$ & $?$ & $?$ & $?$ & $?$ \\
\hline Respi-Neb & $?$ & $?$ & $?$ & $?$ & $?$ & $?$ \\
\hline $\begin{array}{l}\text { Respirgard II } \dagger \\
\text { Sandoz }\end{array}$ & 1.3 & $\frac{9}{2}$ & $?$ & $?$ & $\stackrel{?}{j}$ & $\frac{1.88}{2}$ \\
\hline $\begin{array}{l}\text { Sandoz } \\
\text { Medic-Aid Sidestream }\end{array}$ & 0.7 & 12 & ?: & 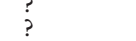 & 83 & 3.18 \\
\hline System 22 Mizer & 2.0 & 15 & $?$ & $?$ & 73 & 4.65 \\
\hline Turret Turbo & & 20 & $?$ & $?$ & 73 & $?$ \\
\hline $\begin{array}{l}\text { Unicorn } 1035 \\
\text { Unineb }\end{array}$ & $?$ & 10 & $?$ & $?$ & 68 & $?$ \\
\hline $\begin{array}{l}\text { Unineb } \\
\text { Upmist }\end{array}$ & $?$ & $?$ & $?$ & & $?$ & $?$ \\
\hline $\begin{array}{l}\text { Upmist } \\
\text { Venticaire }\end{array}$ & $j$ & 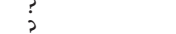 & $?^{?}$ & $?$ & ? & $j_{j}^{?}$ \\
\hline Medic-Aid Ventstream & 1.0 & 10 & $?$ & $?$ & 86 & 3.17 \\
\hline $\begin{array}{l}\text { Wee Neb } \\
\text { Wrijht }\end{array}$ & & $?$ & $?$ & $?$ & $?$ & $?$ \\
\hline Wright & & 20 & $?$ & ? & 83 & $?$ \\
\hline
\end{tabular}

The data in this table have been compiled from various sources and provide a guide only. Whilst the residual and maximum fill obtained for a fill volume of $2-2.5 \mathrm{ml}$ and is generally taken from data obtained with its retail compressor. The $\%$ of particles under $5 \mu \mathrm{m}$ is taken from various sources. Where a ? appears there are no data currently available from any known source. ebuliser chamber (Type 2) and on type of compressor unit. Data are for diaphragm/rotary piston † Data with pentamidine.

BRONCHODILATOR THERAPY

We have divided some currently available nebuliser/compressor combinations into three bands based on the flow rate at the nebuliser (table 1). High flow rate combinations produce more than $50 \%$ of the particle size output less than $5 \mu \mathrm{m}$ diameter and have an MMD of less than $5 \mu \mathrm{m} .{ }^{71619-21}$ The lower flow rate combinations have less than $40 \%$ of their particle size output below $5 \mu \mathrm{m}$ diameter and an MMD of more than $9 \mu \mathrm{m}$. The performance of some of the nebuliser chambers is given in table 2. Particle size distributions may differ with different combinations of nebuliser and compressor (fig 2) Breath assisted nebulisers such as the Ventstream and Pari LC have been shown to have improved performance. ${ }^{2}$

An important point about nebulising bronchodilator drugs is whether or not there is a need for a specific combination or combinations. Whilst there are criteria for attaining an optimal performance, this may not matter in practice since subjective benefit and objective bronchodilatation are the most important factors. There are a number of nebuliser/compressor combinations currently available that do not achieve the standard criteria. ${ }^{7}$ However, these systems are still being used and there have been no reports to suggest that long term use of a poor performance system has resulted in either a reduction in the quality of life or increase in hospital admissions. Part of the reason for this is probably that the doses of bronchodilator drugs being administered are large and that even inefficient systems deliver enough drug to ensure maximal bronchodilatation.

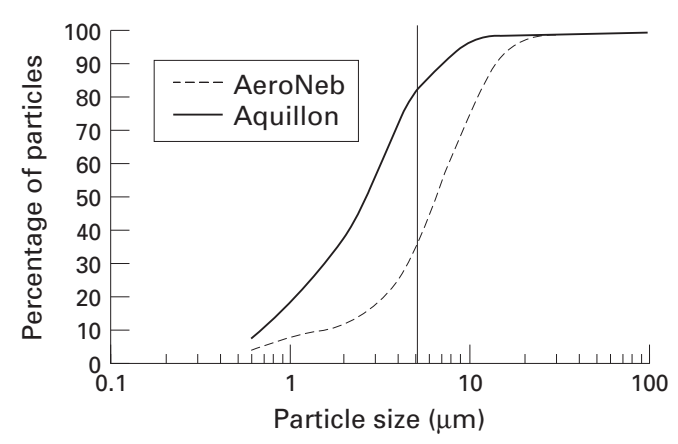

Figure 2 Two examples of particle distribution showing the cumulative percentage of particles within different particle sizes for a high flow rate combination (Aquillon flow rate combination (AeroNeb Standard compressor with Cirrus; flow rate $3 \mathrm{l} / \mathrm{min}$ ). The fill volume in both cases was $2.5 \mathrm{ml}$ of sterile water. For the Aquillon the percentage of particles less than 5 um was $83 \%$, while for the AeroNeb Standard it was 35\%. Based o 
Table 3 Examples of nebuliser/compressor combinations for antibiotic therapy

\begin{tabular}{|c|c|}
\hline Compressor & Nebuliser chamber \\
\hline \multirow{5}{*}{$\begin{array}{l}\text { Medic-Aid CR60 } \\
\text { Medic-Aid Porta-Neb } \\
\text { Medic-Aid CR50 } \\
\text { AFP Tourer } \\
\text { AFP Classic } \\
\text { AFP Aquillon } \\
\text { AFP Ultima } \\
\text { Pari TurboBoy } \\
\text { Pari JuniorBoy }\end{array}$} & Respirgard II \\
\hline & $\begin{array}{l}\text { Medic-Aid Ventstream, } \\
\text { Medic-Aid Sidestream, MicroCirrus, Raindrop, Hudson UD II }\end{array}$ \\
\hline & $\begin{array}{l}\text { Medic-Aid Ventstream, MicroMist, } \\
\text { MicroNeb III, MicroCirrus, Medic-Aid Sidestream }\end{array}$ \\
\hline & Pari LC Plus, Pari LC Plus Filter \\
\hline & $\begin{array}{l}\text { Pari LC Plus Junior, Pari LC Plus Filter } \\
\text { Plist }\end{array}$ \\
\hline
\end{tabular}

ANTIMICROBIAL AGENTS

It is preferable for high power nebuliser systems to be used with antibiotics. ${ }^{1624-28} \mathrm{~A}$ powerful, continuously rated compressor should be used (table 3). Various nebuliser chambers have been shown to be acceptable, although in some cases nebulisation times were longer than is perhaps ideally required by the patient. ${ }^{29}$

MUCOLYTICS AND SALINE

Where mucolytics such as acetylcysteine are used, standard delivery systems, as shown in table 1 , can be used. The high and medium flow rate systems appear to be adequate, ${ }^{3031}$ especially since there appears to be little difference in the rate of output of saline and of bronchodilators. ${ }^{14}$

RHDNASE

Current recommendations are based on limited data. ${ }^{32-35}$ rhDNase should be nebulised using a jet nebuliser since ultrasonic nebulisers may inactivate it or have unacceptable aerosol characteristics. Recommended combinations are given in table 4.

STEROIDS

These can be nebulised with medium or high power systems as shown in table 5 .

Volume-time output and fill volume

Four criteria should be considered:

(1) The minimum initial fill volume is determined by the size of the residual volume of the nebuliser chamber. The larger the residual volume, the greater the initial fill volume will need to be. ${ }^{91722}$ The residual volume of the modern, small volume, nebuliser chambers is less than $1.0 \mathrm{ml}$ (table 2) and for these a fill volume of $2.0-2.5 \mathrm{ml}$ of drug solution is

Table 4 Recommended nebuliser/compressor combinations

\begin{tabular}{ll} 
for rhDNase therapy & \\
\hline Compressor & Nebuliser chamber \\
\hline Pulmo-Aide & Hudson T Up-draft II \\
& Airlife Misty \\
& Al1 \\
Pari InhalierBoy & Pari LL, Pari LC \\
Pari TurboBoy & Pari LC Plus \\
Aiolos & Aiolos \\
Medic-Aid Porta-Neb & Medic-Aid Sidestream \\
Medic-Aid CR50 & Medic-Aid Sidestream \\
Medic-Aid CR60 & Medic-Aid Sidestream \\
AFP Aquillon & MicroMist \\
\hline
\end{tabular}

Data from studies using Pulmozyme.

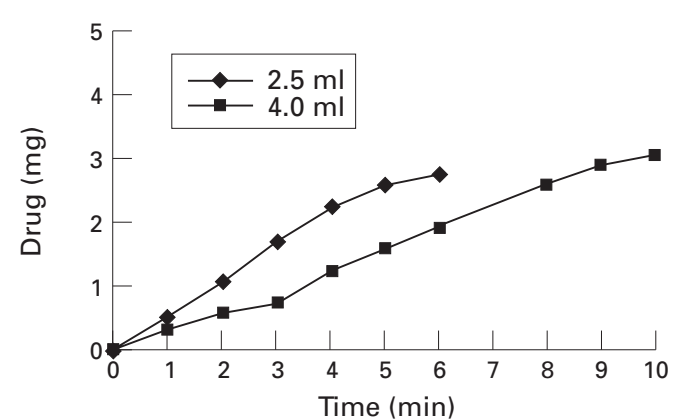

Figure 3 Comparison of rate of delivery of drug with a $2.5 \mathrm{ml}$ and a $4.0 \mathrm{ml}$ fill volume. The $2.5 \mathrm{ml}$ fill volume delivers the same amount of drug as the $4.0 \mathrm{ml}$ fill volume
but in approximately half the time. Data obtained using a Sidestream nebuliser under simulated tidal breathing using compressed air to drive the nebuliser. The residual volume "dryness" wor a fill volume of $2.5 \mathrm{ml}$ nebulisation time to dryness" was six minutes which increased to 10
using the $4 \mathrm{ml}$ fill volume. The $70 \%$ increase in nebulisation time increased the drug output by only $12 \%$.
Data from reference 12 . Reproduced from reference 9 with permission.

enough. Increasing the fill volume with a small volume nebuliser (Sidestream) will (he samer a longer period of time (fig 3).2 Where the residual volume is greater than $1.0 \mathrm{ml}$, a larger initial fill volume is required. Since many nebuliser drugs are now available in prepackaged ampoules of $2.0 \mathrm{ml}$ or $2.5 \mathrm{ml}$, it is important to ensure that the nebuliser chamber used by a patient either has a small residual volume or that the patient is instructed to dilute the contents of the ampoule with normal saline and to make up the initial fill volume to at least twice the size of the residual volume. Table 6 lists suitable combinations of nebuliser chambers and drug ampoules

(2) The time taken to deliver the drug is important for patient compliance. The optimum time for nebulisation is $5-10$ minutes. mum time for nebulisation is $5-10$ minutes. times (fig 4), especially if the treatment is required several times per day. ${ }^{29}$

(3) The end point of nebulisation needs to be defined. There is some evidence that nebulising "to dryness" is confusing for patients and is difficult for them to define (fig 5). Jet nebulisers nebulise continuously until the fill volume approaches the residual volume and "spluttering" occurs. ${ }^{36}$ At this point, although

Table 5 Examples of nebuliser/compressor combinations suitable for corticosteroid therapy

\begin{tabular}{ll}
\hline Compressor & Nebuliser chamber \\
\hline Medic-Aid Porta-Neb & Medic-Aid Ventstream \\
& Medic-Aid Sidestream \\
& Cirrus \\
& Hudson \\
Medic-Aid Freeway & Turret \\
Medic-Aid CR60/CR50 & Cedic-Aid Ventstream \\
& DeVilbiss 646 \\
& Hudson Up-draft II \\
TFP Aquillon & Turret \\
AFP Tourer & Medic-Aist \\
AFP Uidestream \\
Pari Ultima & Medic-Aid Sidestream \\
Pari JuniorBoy & Pari LC Plus, LC Plus Junior \\
\hline Data from various sources. This list is not exhaustive and other
\end{tabular}

Data from various sources. This list is not exhaustive and other 
Table 6 Nebuliser chambers suitable for use with proprietary pre-packaged nebuliser solutions

\begin{tabular}{|c|c|c|c|}
\hline Drug & Trade name & Ampoule size (ml) & Nebuliser chambers \\
\hline Terbutaline & Bricanyl Respules & 2.0 & \\
\hline \multirow[t]{2}{*}{ Ipratropium $\dagger$} & Atrovent & 2.0 & Cirrus, Medic-Aid Sidestream, \\
\hline & Steri-Neb ipratropium & 2.0 & $\begin{array}{l}\text { Haem Nuova 1ypes } 2 \text { and 3, } \\
\text { MicroNeb, }\end{array}$ \\
\hline $\begin{array}{l}\text { Salbutamol/ipratropium } \\
\text { Salbutamol }\end{array}$ & $\begin{array}{l}\text { Combivent } \\
\text { Steri-Neb Salamol } \\
\text { Ventolin Nebules }\end{array}$ & $\left.\begin{array}{l}2.5 \\
2.5 \\
2.5\end{array}\right\}$ & As $2.0 \mathrm{ml}$ plus Respirgard \\
\hline Fenoterol/ipratropium & Duovent & 4.0 & $\begin{array}{l}\text { All of above, plus A11, Hudson, } \\
\text { Pari Boy }\end{array}$ \\
\hline Budesonide & Pulmicort Respules & 2.0 & $\begin{array}{l}\text { Medic-Aid Ventstream, } \\
\text { Cirrus, Turret, } \\
\text { Hudson MicroMist, } \\
\text { DeVilbisis 646, } \\
\text { Pari LC Plus, LC Plus Junior }\end{array}$ \\
\hline Sodium cromoglycate & Intal & 2.0 & As above for $2.0 \mathrm{ml}$ \\
\hline Dornase alpha & Pulmozyme & 2.5 & $\begin{array}{l}\text { Hudson UD II, Acorn, Medic-Aid } \\
\text { Sidestream, Medic-Aid } \\
\text { Ventstream, Aiolos, Pari LC Plus }\end{array}$ \\
\hline
\end{tabular}

It is taken that at least $50 \%$ of the drug solution should be available for nebulisation and without the need for dilution with normal saline. Data from British National Formulary.
$t$ Also available in $1.0 \mathrm{ml}$ ampoules containing $250 \mu \mathrm{g} / \mathrm{ml}$. The $2.0 \mathrm{ml}$ ampoule contains $500 \mu \mathrm{g} / \mathrm{ml}$. Use of the $1.0 \mathrm{ml}$ ampoule
will need dilution as no nebuliser chamber has a residual volume of less than $0.5 \mathrm{ml}$.
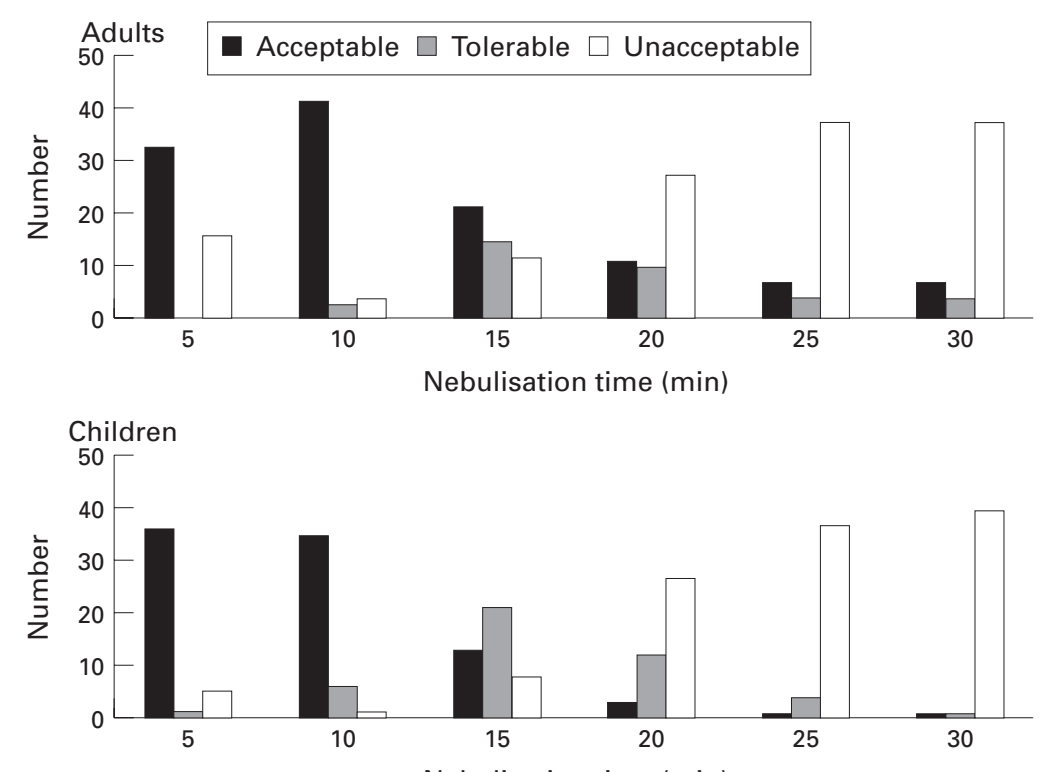
Figure 4 Patient acceptability of different durations of nebuliser treatments. Most patients
preferred a treatment time of 10 minutes or less. Unpublished data from $R S E$ Wilson.

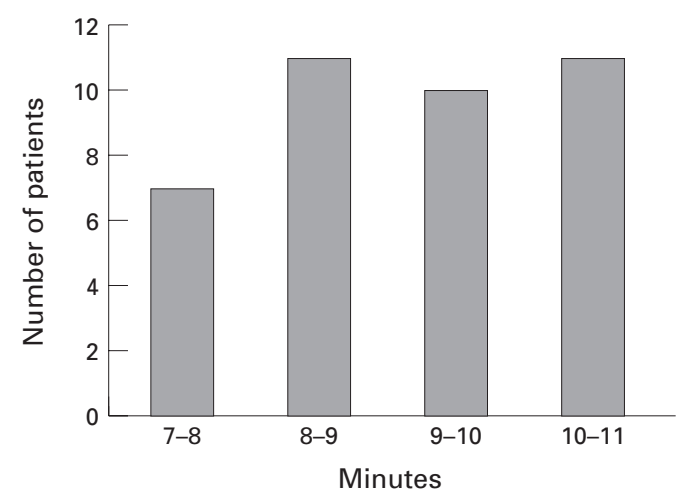

Figure 5 Recognition by patients of "dryness" at the end of nebulisation. The combination of a Charles Austen compressor with a MiniNeb nebuliser would usually reach $2.0-2.5 \mathrm{ml}$. Following explanation of the meaning of "dryness", patients timed the system to "dryness" with stopwatch in minutes and seconds ( $n=39$ episodes). volume output is reduced because of evaporation, drug output remains high for a short period of time (fig 6). This suggests that patients should be told to nebulise until spluttering occurs and then to continue for a further minute. Previous tests should have shown that, with the fill volume used, the system reaches this point in 10 minutes or less. It is essential that the compressor/nebuliser combination is working efficiently and has no faults.

(4) During nebulisation (particularly with new units) large particles tend to adhere to the sides of the nebuliser. Adherence becomes less as the nebuliser ages. These large particles can be encouraged to fall back into the well of the chamber by tapping the side of the nebuliser chamber once the nebuliser begins to "splutter". There is evidence that this may improve output by up to $50 \%$ over a given period of time (fig 7 )

Ease of use

The choice of nebuliser chamber should, to some extent, be based on its ease of use. In general, chambers should (1) not contain components that can be easily swallowed by small children (ideally, all nebulisers should consist of a removable top and the single component chamber); (2) be easily disassembled and reassembled by patients of all ages (this is particularly important in the elderly and in patients whose manual dexterity is significantly imwhose mancla comcan be left connected to the compressor, rest on a flat surface, or be mounted on the compressor itself, and so be filled easily.

Mouthpieces/face masks and venting circuits

Lung deposition is the same in adults or older children, when either a mouthpiece or face mask can be used. ${ }^{3738}$ Face masks are better for infants and younger children, and for emergencies. Mouthpieces are recommended when steroids or anticholinergics are being nebulised. 

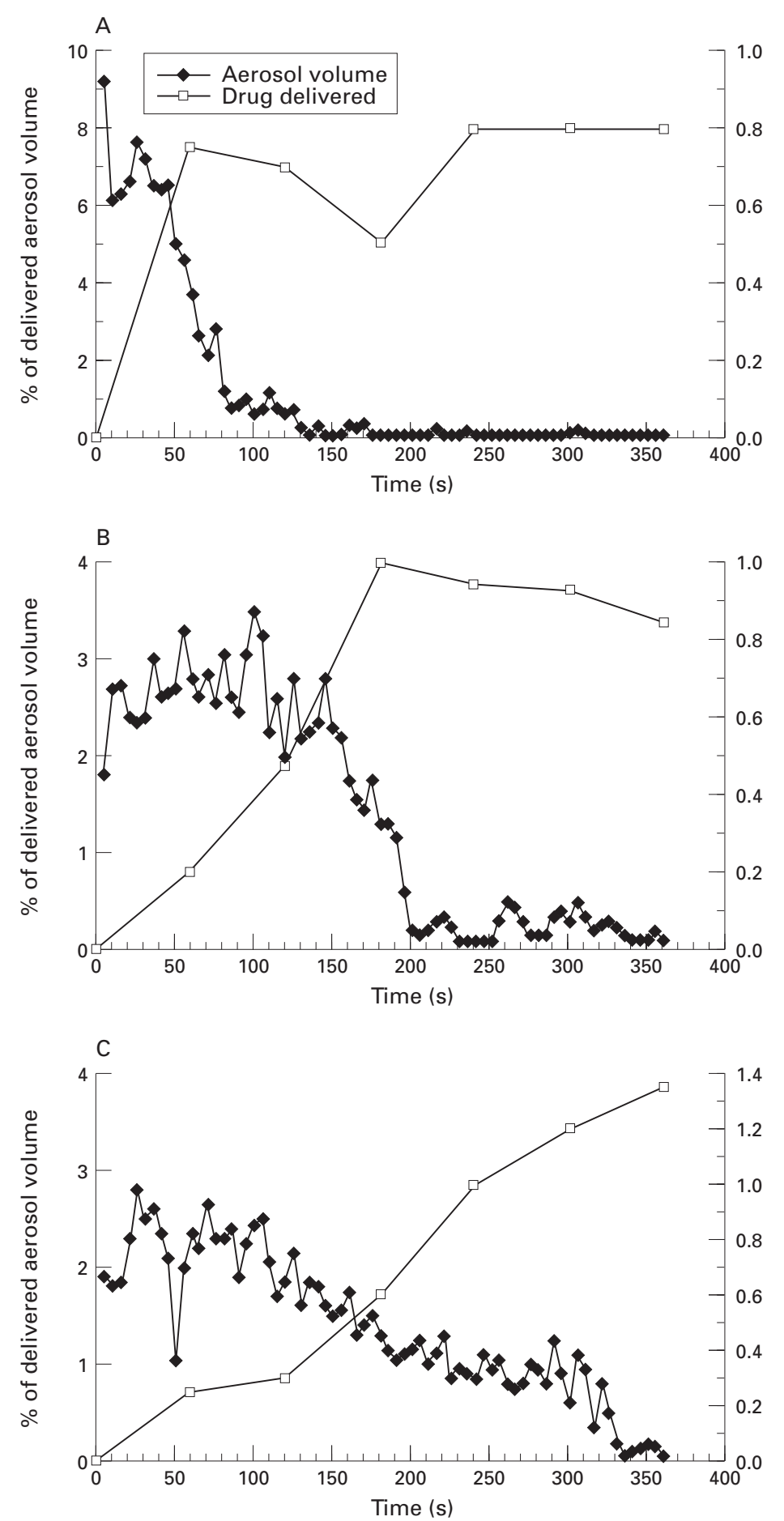

Figure 6 Aerosol output rate (percentage of aerosol delivered every five seconds) and drug output for initial fill volumes of $(A) 1.5 \mathrm{ml}$, (B) $2.5 \mathrm{ml}$, and (C) $3.5 \mathrm{ml}$ plotted compressor were used. With a fill volume of $1.5 \mathrm{ml}$ there was an abrupt fall in output after 45 seconds whilst with fill volumes of $2.5 \mathrm{ml}$ and $3.5 \mathrm{ml}$ the fall-off points were 160 seconds and 320 seconds, respectively. Each of these abrupt fall-off points corresponded to the onset of nebuliser "spluttering" - the point where the droplet rain-off from the nebulis waalls is insufficient to supply aerosol for renebulisation. There is an audible change in approximately these points with the $1.5 \mathrm{ml}$ and $2.5 \mathrm{ml}$ fill volumes. Redrawn with permission from reference 36.

If a face mask is used it should be closely fitting to the face and should not be held away from the face.

BRONCHODILATORS

Usually the choice depends on patient preference. Use of ipratropium bromide poses potential problems in patients with glaucoma. There have been no long term studies but short term studies in normal subjects and in patients with narrow angle glaucoma show that up to four times the recommended dose of inhaled ipratropium has no effect on intraocular pressure, pupil diameter, or accommodation..$^{39-41}$ However, prolonged pupillary dilation occurs However, prolonged pupillary dilation occurs
if ipratropium is sprayed directly into the eye. ${ }^{42}$ if ipratropium is sprayed directly into the eye. ${ }^{42}$ The addition of salbutamol intensifies the risk,
especially in patients with glaucoma, ${ }^{4344}$ so patients should be carefully instructed in the use of nebulised anticholinergic agents, ensuring that a face mask is tight fitting, or preferably, that administration occurs via a mouthpiece.

ANTIBIOTICS

There are possible risks to staff associated with exposure to antibiotics (see paper by Webb and Dodd on pp S69-71), so it is important that the circuit should contain either a filter or the exhaled air be vented directly to the external atmosphere by wide bore tubing through an open window. Where appropriate filters are available, these should be used in preference to venting. Mouthpieces should be used.

Appropriate antibiotic T-pieces and circuitry is important to prevent waste from the system polluting the surrounding atmosphere, although there is no published medical evidence to indicate that pollution of the hospital atmosphere may lead to the establishment of resistant organisms.

STEROIDS, PENTAMIDINE

Mouthpieces are the preferred option.

छิ

Single use or single patient use?

The Medical Devices Agency has recently issued a bulletin ${ }^{45}$ regarding the use of devices such as nebulisers for single use or single patient use. Where nebulisers are marked by the manufacturer as "single use" they may only be used once and should then be discarded. Where nebulisers are marked "single patient use" then they are reusable items that are capable of being reused, with or without reprocessing, by an individual patient. Some nebuliser chambers are reusable and so may be used on different patients as long as appropriate reprocessing, as indicated by the manufacturer, is followed.

Whilst nebuliser chambers have been categorised as "single patient use" for many years throughout the world, this new clearly defined categorisation of the use of devices means that both the manufacturer and physician in charge should define the extent and the methods by which "single patient us" devices shoud be " devices should be used and reprocessed. Within the letter of the law, devices marked "single use" should only be used once and then discarded. Reusing such devices may leave the physician and/or the respiratory team open to litigation should any problem arise as a result of using a "single use" device as a "single patient use" device. Manufacturers should mark the packaging of 


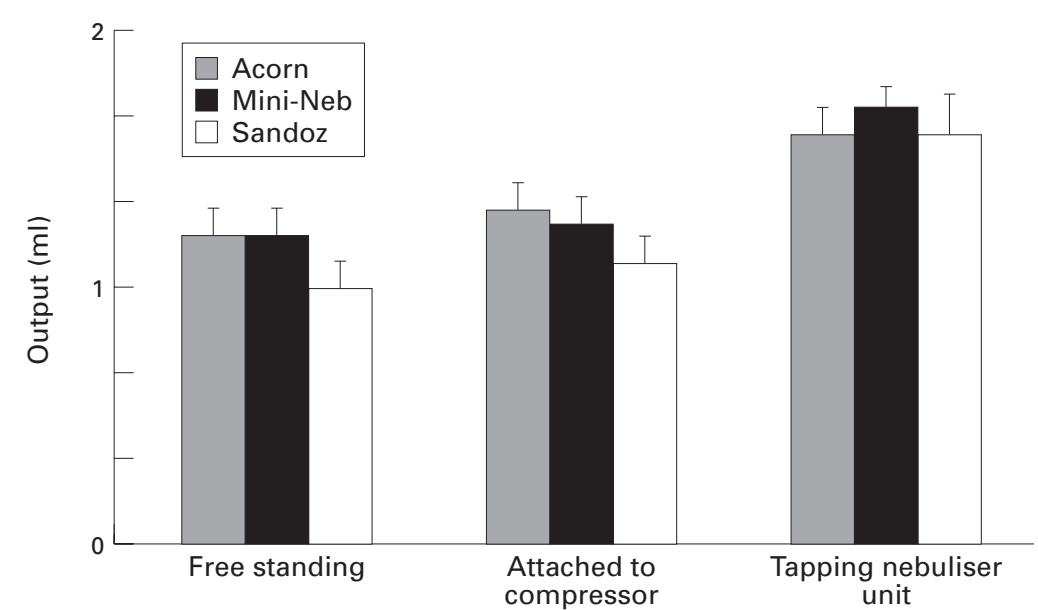

Figure 7 Effects of "tapping" on the volume output from 10 nebuliser units. The incircuit flow was 6-8 l/min, the fill volume was $2.0 \mathrm{ml}$, and the nebulisation time was over 10 minutes. Data from reference 14.

nebuliser chambers as "single use" or "single patient use" and provide instructions for reprocessing of "single patient use". The user must ensure that he or she uses the correct type of device and, if in doubt, should contact the supplier directly. Items that contain no indication of use should be avoided.

One major problem with nebuliser chambers is their potential for cross-infection. To date there does not appear to be any evidence that these devices are responsible for the acquisition of infecting organisms, although bacterial cultures of non-pathogenic organisms have been reported. ${ }^{4647}$ It is therefore important that good hygienic practice is followed ${ }^{48}$ to reduce, as far as possible, any risk of infecting organisms being colonised within the nebuliser chamber.

Further research into this and into aspects Further research into this and into aspects
of the degradation of nebuliser performance of the degradation of nebuliser performance with time are required to clarify the need for
carefully defining how nebuliser chambers are used in practice.

\section{Compressors: other factors for}

\section{consideration}

STANDARDS

All compressors should be certificated to British Standard 5724 or to an European equivalent. The certificate should be from an independent testing authority which should be stated by the manufacturer.

NOISE

Noise can be an important factor in the acceptability of treatment, both to the patients and to their families and friends. The system should be as quiet as possible. An assessment of the noise of a range of devices is depicted in fig 8 which shows the range and how it relates to a variety of defining points used to assess noise pollution. ${ }^{7}$

WEIGHT

To be portable, the compressor and associated components should be as light as possible. This

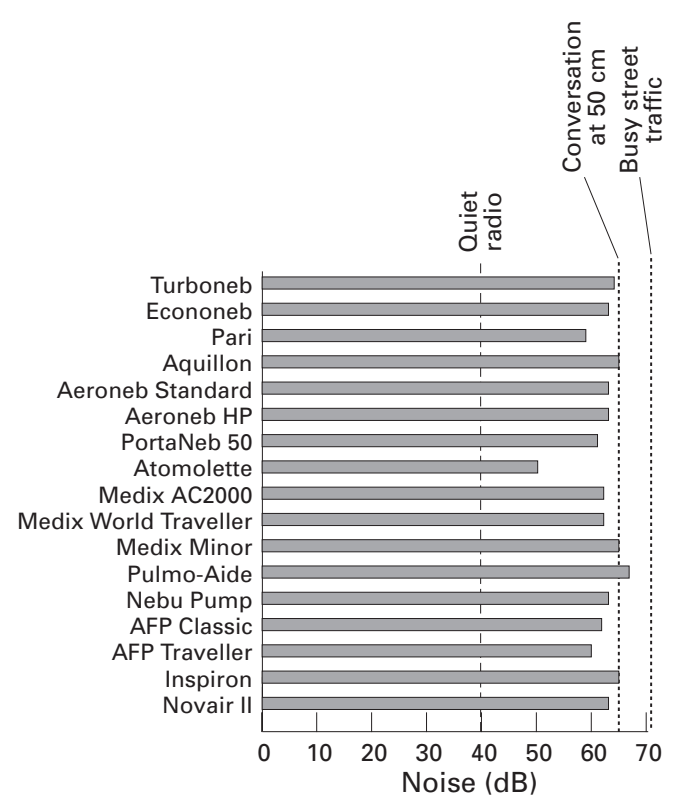

Figure 8 Range of noise encountered when using variou nebuliser/compressor systems. Noise was measured one metre from the combination of nebuliser/compressor using

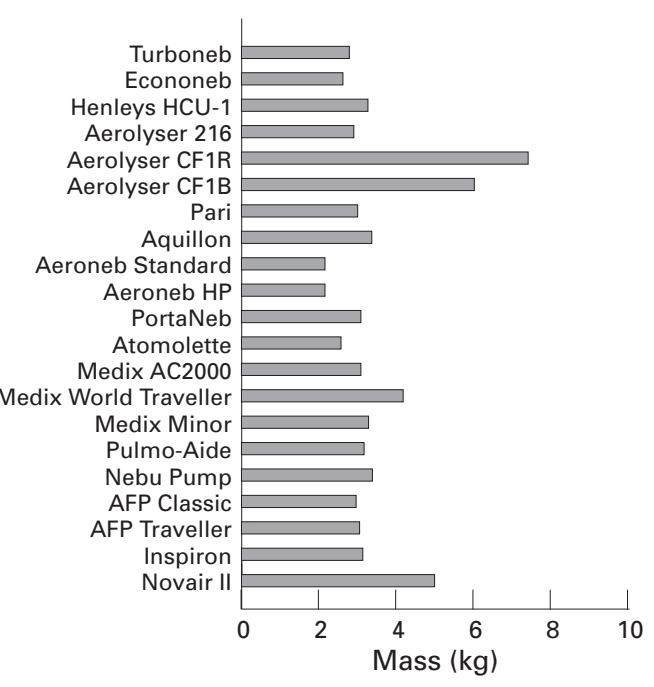

Figure 9 Variation in weight for a number of nebuliser compressor units. Data from references 7 and 17.

is particularly important to patients who have to travel with their system. ${ }^{716}$ The weights of various compressor/nebuliser combinations are shown in fig 9 .

costs

Running costs may be an important consideration for patients with limited income. Low energy consumption units would therefore be appropriate for these patients, so long as the other performance requirements were met. Figure 10 shows the relative costs of various compressors where a patient has four 15 minute nebulisations/day for one year. ${ }^{7}$ These costs are calculated from the power rating 


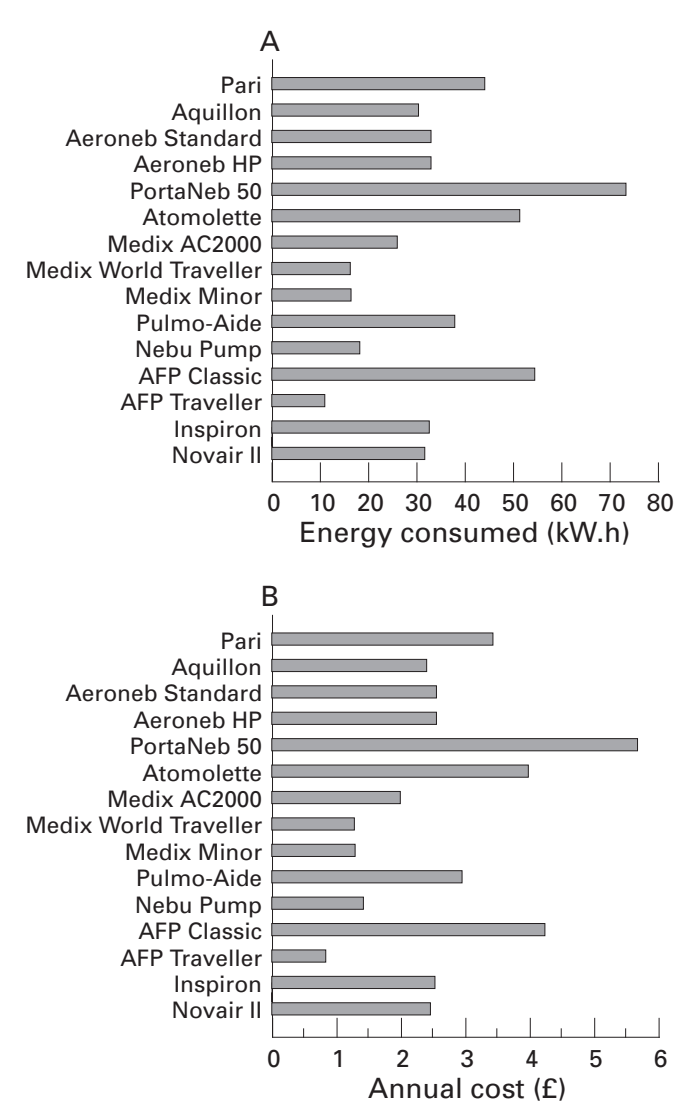

Figure 10 Variation in costs of running a nebuliser/ compressor unit for four periods of 15 minutes per day for one year. The data are presented as energy consumed
$(k W . h)$, the actual cost being dependent on local electricity charges. Data from reference 7 .

(volts $\times$ amps $=$ watts) of the compressor and the cost of a unit $(1 \mathrm{~kW} . \mathrm{h})$ of electricity. Thus, if the compressor is rated at 50 watts a total of 20 hours $(1000 / 50)$ of usage will equal a single unit of electricity. For four 15 minute nebulisations per day, a unit of electricity will be consumed every 20 days. The cost is therefore
$365 / 20$ units multiplied by the cost per unit of $365 / 20$ units multiplied by the cost per unit of
electricity. So, if the unit cost is $£ 0.0773$, the electricity. So, if the unit cost is $£ 0.0773$, the or $£ 1.41$ per year.

POWER SUPPLY

In the UK and many other countries the power supply will be $220-240 \mathrm{~V}$ and $50 \mathrm{~Hz}$. In most of the Caribbean, Canada, Japan, some Middle Eastern countries, the USA, and some parts of South America the voltage is usually $100 / 110$ V. It is therefore important that devices should be available for the patient using nebulisers who wishes to travel abroad. A few systems are multivolt and can be run at $100 / 110 \mathrm{~V}$ or on a 12 V DC source for use with car batteries. $12 \mathrm{VDC}$ source for use with car batteries.
Those systems which are multivolt are indicated in table 1 .

\section{Conclusion}

From the evidence presented it appears that the nebuliser/compressor should be able to deliver $2.0-2.5 \mathrm{ml}$ of bronchodilator solution at a constant rate, with the particle size such that most are less than $5 \mu \mathrm{m}$. For other substances the evidence is less clear.

\section{For the future}

The major problem encountered in choosing the appropriate combination of nebuliser and compressor is the scarcity of consistent information. There is clearly a need for the assessment of all possible combinations currently available, and there must also be a clear consensus as to what information is essential and what is helpful but secondary in use.

To provide information on every combination of nebuliser and compressor will be difficult, time consuming, and expensive. However, if a number of laboratories were to be accredited to perform comparisons to set protocols, much of the difficulty in making statements about nebuliser and compressor combinations for the various nebulised drugs would be reduced.

1 Brain JD, Valberg PA. Deposition of aerosol in the respiratory $2 \mathrm{O}^{\prime}$ Callaghan $\mathrm{C}$. How to get drugs into the respiratory tract. Arch Dis Child 1993;68:441-3.

response to inhaled bronchodilators. Eur f Respir Dis 1982 ;
rese 63(Suppl 119): 73-8.

4 Swift DL. Generation and respiratory deposition of thera-

peutic aerosols. Am Rev Respir Dis 1980;122:71-7.
5 Mercer TT. Production and characterisation of aerosol.

Arch Intern Med 1973;131:39-50.

6 Byron PR. Aerosol formulation, generation and delivery

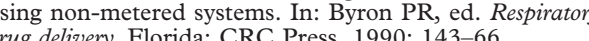
7 Smith EC, Denyer J, Kendrick AH. Comparison of 23 nebuliser/compressor combinations for domiciliary use. Eur
Respir $71995 ; 8: 1214-21$.

8 Dennis JH, Stenton SC, Beach JR, Avery AJ, Walters EH, Dewdrick DJ. Jet and ultrasonic nebuliser output: use of a
new method for direct measurement of aerosol output. new method for direct measurement of aerosol output.
Thorax 1990;45:728-33.

9 Kendrick AH, Smith EC, Denyer J. Nebulisers - fill volume, residual volume and matching of nebuliser to compressor. Respir Med 1995;89:157-9.
Clay MM, Pavia D, Newman SP, Clarke SW. Factors influencing the size distribution of aerosols from jet nebulisers. Thorax 1983;38:755-9.
Douglas JG, Leslie MJ. Crompton GK, Grant IWB. Is the Douglas JG, Leslie MJ, Crompton GK, Grant IWB. Is the BMF 1985;290:29-32. Denyer J, Dyche T, Smith EC, Kendrick AK. The optimum
volume for nebulization of bronchodilators. Eur Respir $\mathcal{I}$ 1993,6(Suppl 17):148s of , K medical atomisers (nebulisers) for drug solutions of different viscosities and surface tensions. Atom Spray Techno 14 Steventon RD, Wilson RSE. A guide to apparatus for hom

15 Hurley PK, Smye SW. Assessment of antibiotic aeroso

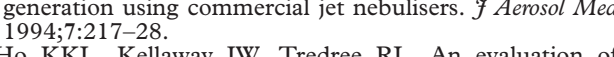
6 Ho KKL, Kellaway IW, Tredree RL. An evaluation of
powered nebulisers. Health Equipment Information No powered nebulisers. Health Equipment Information No
180 . Department of Health and Social Security, 1980. Clay MM, Pavia D, Newman SP, Lennard-Jones T, Clarke SW. Assessment of jet nebulisers for lung aerosol therapy.

Lancet 1983;iii:592-4.
18 Everard ML, Clarke AE, Milner AD. Drug delivery from 9 Hurley PK, Smye SW. Peild 1992;67:586-91. of commercial jet nebulisers. Technol Health Care 1994;1: 0 Loffert

jeffert DT, Ikle D, Nelson HS. A comparis
jet nebulisers. Chest 1994;106:1788-92. Phillips P, Fisher B, Toyick N, Jenkins V. Performance gical Materials Testing Laboratory, Bridgend General Hos-

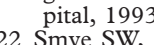

Smye SW, Shaw A, Norwood HM, Littlewood JM. Some factors affecting the efficiency of a jet
Clin Phys Physiol Med 1990;11:167-75.

3 Newman DM, Lipworth BJ. Nebuliser performance, pharacokinetics, airways and systemic effects of salbutamol Thorax 1994;49:762-70 Newman SP, Pellow PGD, Clay MM, Clarke SW. Evaluation of jet nebulisers for use with gentamicin solution 
25 Newman SP, Pellow PGD, Clarke SW. Efficient nebulization of powdered antibiotics. Int $\mathcal{F}$ Pharm 1987;36:55-60.

26 Newman SP, Pellow PGD, Clarke SW. Choice of nebulisers and compressors for delivery of carbenicillin aerosol. Eu
$\exists$ Respir Dis 1986;69:160-8. O'Roirdan TG, Amram JC. Effect of nebuliser configuration on delivery of aerosolized
Care Med 1995;151:A739. Thomas SHL O'Doherty MJ, Page CJ, Nunan TO, Bateman NT. Which apparatus for inhaled pentamidine? A comparison of pulmonary de

29 Smith G. A patient's view of cystic fibrosis. 7 Adolescent

30 Sutton PP, Gemmell HG, Innes N, Davidson I, Smith FW, Legge JS, et al. Use of nebulised saline and nebulised terbutaline as an adjunct to chest physiotherapy. Thorax
1988;43:57-60. Pavia D, Sutton PP, Lopez-Vidriero MT, Newman SP,
Clarke SW. Drug effects on mucociliary clearance. Eur 9 Respir Dis 1983;64 (Suppl 128):304-1

32 Hung JCC, Hambleton G, Super M. Jet nebulisers for recombinant human DNase 1. Arch Dis Child 1994;71:
$558-9$.
O'Roirdan TG, Wilson JM, Robinson CB. Evaluation of O'Roirdan TG, Wilson JM, Robinson CB. Evaluation of
delivery systems for aerosolization of recombinant gene delivery systems for aerosolization of recombinant gene
therapy for cystic fibrosis. Am $\mathcal{F}$ Respir Crit Care Med 1995 ; 151:A19. Shah PL, Scott SF, Fuchs HJ, Geddes DM, Hodson ME
Medium term treatment of stable stage cystic fibrosis with recombinant human DNase I. Thorax 1995;50:333-8. Cipolla D, Gonda I, Shire SJ. Characterisation of aerosols
of human recombinant deoxyribrose nuclease 1 generated of human recombinant deoxyribrose nuclease 1 generated
by jet nebulisers. Pharm Res 1994;2:491-8. Malone RA, Hollie MC, Glynn-Barnhart A, Nelson HS Optimal duration of nebulised albuterol therapy. Chest
1993;104:1114-8. 37 Steventon RD, Wilson RSE. Facemask or mouthpiece for
delivery of nebulized bronchodilator aerosols. $\mathrm{Br} F$ Dis Whest 1981;75:88-90. Aust Paediatr 7 1978; 14:150-3. Rustin RE, Wolf RK, Dolovich MB, Rossman CM, Fitz-
gerald JD, Newhouse MT. Aerosol therapy with Sch 1000: gerald JD, Newhouse MT. Aerosol therapy with Sch 1000:
short-term mucociliary clearance in normal and bronchitic $501-6$.
Scheufler G. Ophthalmotonometry, pupil diameter and 40 Scheufler G. Ophthalmotonometry, pupil diameter and
visual accommodation following repeated administration
of Sch 1000 MDI in patients with glaucoma (abstract). 41 Postgrad Med F $1975 ; 51$ (Suppl 7): 132. MDI in healthy volunteers and patients with glaucoma
(abstract). Postgrad Med f 1975;51(Suppl 7):132-3. Samaniego F, Newman LS. Migratory aniscoria: a novel clinical entity (letter). Am Rev Respir Dis 1986;143:844.
Kalra L, Bone M. The effect of nebulized bronchodilato therapy on intraocular pressure in patients with glaucoma. Chest 1988;93:739-41.
Shah Phurion L, Metcalfe T, Gibson JM. Acute angle
glaucoma associated with nebulized ipratropium bromide and salbutamol. $B M F$ 1992;304:40-1.

Medical Device Bulletin No. 9501 . The reuse of medical
derices suphlied for single use only. London: Medical Devices devices supplied for single use only. London: Medical Devices
Agency, 1995 .
Higns CMB, Harvey JE, Jones P, Tanser AR. Effect of long 46 Higgs CMB, Harvey JE, Jones P, Tanser AR. Effect of long
term domiciliary nebuliser therapy. Thorax 1984;39:689. term domiciliary nebuliser therapy. Thorax $1984,39: 689$.
4 Hutchinson GR, Parker S, Pryor J. Home-use nebulisers: a potential source of Burkholderia cepacia and other colistin-
resistant, gram negative bacteria in patients with cystic resistant, gram negative bacteria in paic
fibrosis. F Clin Microbiol 1996;34:584-7.

Dodd M, Eveleigh M. Nebulizer therapy - your questions
answered. How do I clean my nebulizer? answered. How do I clean my nebulizer? National Asthma
Training Centre and Medic-Aid Ltd, 1995: 11-12. 


\section{Appendix: Suppliers of nebulisers and compressors}

\begin{tabular}{|c|c|c|}
\hline $\begin{array}{l}\text { Aerosol Medical Ltd } \\
\text { Wyncolls Road } \\
\text { Colchester } \\
\text { Essex CO4 4HT, UK }\end{array}$ & Tel: +441206842244 & $\begin{array}{l}\text { Wright nebuliser } \\
\text { Aerolyser CF1B } \\
\text { CF1R, } 216\end{array}$ \\
\hline $\begin{array}{l}\text { AFP Medical } \\
71 \text { Somers Road } \\
\text { Rugby } \\
\text { Warwickshire } \\
\text { CV22 7DG, UK }\end{array}$ & $\begin{array}{l}\text { Tel: + } 441788578121 \\
\text { Fax: + } 441788540199\end{array}$ & $\begin{array}{l}\text { AFP Classic } \\
\text { AFP Tourer } \\
\text { AFP Aquillon } \\
\text { AFP Ultima } \\
\text { Hudson MicroMist }\end{array}$ \\
\hline $\begin{array}{l}\text { Bard Ltd } \\
\text { Pennywell Industrial Estate } \\
\text { Sunderland } \\
\text { SR4 9EW, UK }\end{array}$ & Tel: +441915343131 & $\begin{array}{l}\text { Incenti-Neb nebuliser } \\
\text { Inspiron MiniNeb } \\
\text { Inspiron compressor }\end{array}$ \\
\hline $\begin{array}{l}\text { Carri-Med Ltd } \\
\text { Glebelands Centre } \\
\text { Vincent Lane } \\
\text { Dorking RH4 3YX } \\
\text { UK }\end{array}$ & Tel: +441306 886180 & $\begin{array}{l}\text { Nebupump } \\
\text { compressor }\end{array}$ \\
\hline $\begin{array}{l}\text { DeVilbiss Healthcare } \\
\text { Airlinks, Spitfire Way } \\
\text { Heston } \\
\text { Middlesex TW5 9NR } \\
\text { UK }\end{array}$ & $\begin{array}{l}\text { Tel: +441817561133 } \\
\text { Fax: +441815731769 }\end{array}$ & $\begin{array}{l}\text { SunMist } \\
\text { SunMist Plus } \\
\text { DeVilbiss Traveller } \\
\text { Perma Neb }\end{array}$ \\
\hline $\begin{array}{l}\text { Flaem Nuova } \\
\text { Via Colli Storici 73-25010 } \\
\text { S Martino Della Battaglia } \\
\text { Brescia } \\
\text { Italy }\end{array}$ & $\begin{array}{l}\text { Tel: + } 39309910168 \\
\text { Fax: +39309910287 }\end{array}$ & $\begin{array}{l}\text { Type } 2 \text { nebuliser } \\
\text { Type } 3 \text { nebuliser } \\
\text { TravelNeb } \\
\text { Combineb, M70 } \\
\text { Micelfluss Pro }\end{array}$ \\
\hline $\begin{array}{l}\text { Henleys Medical Supplies } \\
\text { Alexandra Works } \\
\text { Clarendon Road } \\
\text { Hornsey } \\
\text { London N8 ODL } \\
\text { UK }\end{array}$ & Tel: +441818893151 & $\begin{array}{l}\text { Cloud Chamber } \\
\text { nebuliser } \\
\text { Hudson UD II } \\
\text { nebuliser } \\
\text { HCU-1 compressor }\end{array}$ \\
\hline $\begin{array}{l}\text { Intersurgical } \\
\text { Molly Millars Lane } \\
\text { Wokingham } \\
\text { Berkshire RG11 2RZ } \\
\text { UK }\end{array}$ & $\begin{array}{l}\text { Tel: +441734795579 } \\
\text { Fax: +44 } 1734795555\end{array}$ & $\begin{array}{l}\text { Cirrus, MicroCirrus } \\
\text { Novair compressor }\end{array}$ \\
\hline $\begin{array}{l}\text { Lifecare Hospital Supplies } \\
\text { 28A Scotland Road } \\
\text { Market Harborough } \\
\text { Leics LE16 8AX } \\
\text { UK }\end{array}$ & Tel: +441858 431455 & MicroNeb \\
\hline $\begin{array}{l}\text { Medic-Aid Ltd } \\
\text { Heath Place } \\
\text { Bognor Regis } \\
\text { West Sussex } \\
\text { PO22 9SL, UK }\end{array}$ & $\begin{array}{l}\text { Tel: +441243267616 } \\
\text { Fax: +441243262979 }\end{array}$ & $\begin{array}{l}\text { Sidestream } \\
\text { Ventstream } \\
\text { Porta-Neb } \\
\text { CR50, CR60 } \\
\text { System 22 } \\
\text { Turret nebuliser }\end{array}$ \\
\hline $\begin{array}{l}\text { Medix Ltd } \\
\text { Clement Clarke International Ltd } \\
\text { Edinburgh Way } \\
\text { Harlow } \\
\text { Essex CM20 2TT } \\
\text { UK }\end{array}$ & $\begin{array}{l}\text { Tel: +441279414969 } \\
\text { Fax: +441279635232 }\end{array}$ & $\begin{array}{l}\text { Medix AC2000, World Traveller } \\
\text { Medix M Flo } \\
\text { Medix A11 } \\
\text { Medix TurboNeb }\end{array}$ \\
\hline $\begin{array}{l}\text { Pari GmbH } \\
\text { Moosstrasse } 9 \\
\text { D-82319 Starnberg } \\
\text { Germany }\end{array}$ & $\begin{array}{l}\text { Tel: +49 } 8151279-0 \\
\text { Fax: + } 498151279-101\end{array}$ & $\begin{array}{l}\text { Pari LC Plus } \\
\text { Pari InhalierBoy }\end{array}$ \\
\hline $\begin{array}{l}\text { Sinclair Medical Ltd } \\
\text { Borough Road } \\
\text { Godalming } \\
\text { Surrey, GU7 2AB } \\
\text { UK }\end{array}$ & Tel: +44 1928717070 & $\begin{array}{l}\text { Atomolette } \\
\text { nebuliser/compressor }\end{array}$ \\
\hline
\end{tabular}

